\title{
EFEKTIVITAS PERANAN MAJELIS PENGAWAS DAERAH (MPD) KOTA BATAM DALAM PENEGAKAN KODE ETIK BERDASARKAN UNDANG-UNDANG NOMOR 2 TAHUN 2014 TENTANG PERUBAHAN ATAS UNDANG-UNDANG NOMOR 30 TAHUN 2004 TENTANG JABATAN NOTARIS (STUDI LAPANGAN DI KOTA BATAM)
}

\author{
Johnson Wijaya $^{1}$ \\ Diana $^{2}$
}

\begin{abstract}
The implementation of this research was carried out with the aim of knowing the concept of the application of supervisory by the investigator and the effectiveness of the application of the diversion to the Notary who violated the Notary code of ethics in the Batam city area.

This research was carried out by the author using empirical legal research methods because in this study the authors used primary data that the author obtained from the Notary investigator, especially in the Batam City Regional Supervisory Assembly unit through interviews and collecting data relating to cases that occurred in the field then the authors review it using the theory of legal effectiveness that was presented by legal expert Soejono Soekanto on the application of diversions that have been carried out within the Batam City area and the authors also review using secondary data in the form of several literature literature and legal science books relating to the subject matter which the author carefully in this thesis.

Based on the results of the research that the author has done, it can be concluded that the application of sanctions by the Supervisory party at the investigation stage is still considered to be not fully effective as reviewed based on the theory of legal effectiveness presented by legal expert Soejono Soekanto.
\end{abstract}

Keywords: Notary, system for implementing supervisory by the Regional Supervisory Board

\footnotetext{
${ }^{1}$ Fakultas Hukum Universitas Internasional Batam

${ }^{2}$ Fakultas Hukum Universitas Internasional Batam
} 


\section{A. Latar Belakang}

Jasa Notaris pada era globalisasi saat ini dalam proses pembangunan semakin meningkat. Hal ini dikarenakan Notaris sebagai pejabat umum yang berwenang untuk membuat akta autentik dan memiliki kewenangan lainnya yang dibutuhkan dalam kehidupan sehari-hari yang berkaitan dengan hukum. Sebagai pejabat umum, Notaris mempunyai kedudukan dan peranan yang penting dalam mewujudkan kehidupan bangsa yang bermartabat dan berdaulat yang bernuasa kepastian hukum. Seiring perkembangan kehidupan yang semakin modern, yang diwarnai dengan meningkatnya hubungan-hubungan kontraktual antara sesama warga negara ataupun lembaga-lembaga sosial dan lembaga pemerintah, maka akan terasa sekali pentinya jasa pelayanan Notaris. Terutama dalam hal pembuatan akta-akta Notaris yang mampu memberikan kepastian hukum bagi pihak-pihak yang terlibat dalam kontrak tersebut. Dengan kata lain, sebagai hukum (rechtstaat), Indonesia sangat berkepentingan terhadap keberadaan Notaris yang menjalankan profesi dalam pelayanan hukum kepada masyarakat perlu perlindungan dan jaminan demi tercapainya kepastian hukum. ${ }^{3}$

Setiap menjalankan tugas jabatannya dalam membuat suatu akta, seorang Notaris memiliki tanggung jawab terhadap akta yang dibuatnya sebagai suatu realisasi keinginan para pihak dalam bentuk akta autentik. Tanggung jawab Notaris berkaitan erat dengan tugas dan kewenangan serta moralitas baik sebagai pribadi maupun selaku pejabat umum. Notaris berkaitan erat dengan tugas dan kewenangan serta moralitas baik sebagai pribadi maupun selaku pejabat umum. Notaris mungkin saja melakukan kesalahan atau kekhilafan dalam pembuatan akta. Apabila ini terbukti, akta kehilangan autentisitasnya dan batal demi hukum atau dapat dibatalkan. Notaris rawan terkena jeratan hukum, bukan hanya karena faktor internal yang berasal dari dalam dirinya sendiri misalnya kecorobohan, tidak mematuhi prosedur, tidak menjalankan etika profesi dan sebagainya. Di samping itu faktor internal seperti moral masyarakat dimana Notaris dihadapkan pada dokumen-dokumen palsu padahal dokumen tersebut mengandung konsekuensi hukum bagi pemiliknya. ${ }^{4}$

Fungsi Notaris didalam dan diluar pembuatan akta otentik untuk pertama kalinya diatur di dalam Undang-Undang Nomor 2 Tahun 2014 tentang Perubahan atas Undang - Undang Nomor 30 Tahun 2004 tentang Jabatan Notaris secara komprehensif. Demikian pula ketentuan tentang pengawasan terhadap Notaris yang dilaksanakan oleh Majelis Pengawasan Notaris dilakukan dengan melibatkan pihak ahli akademisi, disamping departemen yang tugas dan tanggung jawabnya dibidang kenotariatan serta Organiasai Notaris, dibentuknya Majelis Pengawasan Notaris di tiap Kota atau Kabupaten dimaksudkan untuk

\footnotetext{
${ }^{3}$ Sri Utami, "Perlindungan Hukum Terhadap Notaris Dalam Proses Peradilan Pidana Menurut Undang-Undang Nomor 2 Tahun 2014 Tentang Perubahan Atas Undang-Undcang Nomor 30 Tahun 2004 Tentang Jabatan Notaris”, artikel pada jurnal Repertorium ISSN: 2355-2646, Edisi 3 januari-juni 2015, hlm.89.

${ }^{4}$ Pengurus Pusat Ikatan Notaris Indonesia, Jati Diri Notaris Indonesia Dulu, Sekarang dan di Masa Datang, PT. Gramedia Pustaka Utama, Jakarta, 2008, hlm. 226.
} 
meningkatkan pelayanan dan perlindungan hukum bagi masyarakat pengguna jasa Notaris.

Peranan Majelis Pengawasan Notaris adalah melaksanakan pengawasan terhadap Notaris, supaya dalam mejalankan tugas jabatannya tidak menyimpang dari kewenangannya dan tidak melanggar peraturan perundang-undangan yang berlaku, fungsi Majelis Pengawas Notaris adalah agar segala hak dan kewenangan maupun kewajiban yang diberikan kepada Notaris dalam menjalankan jabatannya sebagimana yang diberikan oleh peraturan perundang-undangan yang berlaku, senantiasa dilakukan diatas jalur yang telah ditentukan, bukan saja jalur hukum, tetapi juga atas dasar moral dan etika demi terjaminnya perlindungan hukum dan kepastian hukum bagi pihak yang membutuhkannya. Tidak kalah penting juga peranan masyarakat untuk mengawasi dan senantiasa melaporkan tindakan Notaris yang dalam melaksanakan tugas jabatannya tidak sesuai dengan aturan hukum yang berlaku kepada Majelis Pengawasan setempat dengan adanya mengeliminasi tindakan Notaris yang tidak sesuai dengan aturan hukum pelaksanaan tugas jabatan Notaris.

Pada faktanya terjadi penyimpangan-penyimpangan yang banyak dilakukan oleh Notaris dalam melaksanakan kewenangan dan jabatanya. Mulai dari penyimpangan-penyimpangan yang bersifat administratif maupun penyimpanganpenyimpangan yang mengakibatkan kerugian materil pada masyarakat pengguna jasa Notaris. Bahkan terdapat kasus di daerah Tangerang dimana Notaris Raden Meliani Rahmawati SH dinyatakan terbukti bersalah melanggar KUHP pasal 263 dan hanya memberikan hukuman dua tahun masa percobaan. Sesuai fakta persidangan terdakwa dinyatakan terbukti bersalah melakukan perbuatan tindak pidana dengan memalsukan akta orang lain. Vonis dibacakan bahwa Notaris Raden Meliani Rahmawati SH hanya diberikan sanksi hukuman 2 (dua) tahun (masa) percobaan agar tidak melakukan perbuatan yang sama dikemudian hari. Vonis ringan tanpa dipenjara terhadap terdakwa Meliani Rahmawati dijatuhkan oleh Majelis Hakim yang diketuai Elly Noeryasmien. Alasan ketua Majelis Hakim menjatuhkan vonis ringan karena yang bersangkutan selalu kooperatif dan santun selama persidangan. Jaksa Penuntut Umum (JPU) menyatakan putusan Majelis Hakim tidak sesuai dengan tuntutan yang diajukannya 1 tahun penjara. Bahwa penerapan sanksi masih belumlah efektif dikarenakan tidak dapat memberikan efek jera bagi Notaris yang melanggar kode etik dan peraturan perundangundangan sehingga bisa saja perbuatan ini dilakukan kembali dan merugikan kepentingan masyarakat.

Berdasarkan latar belakang diatas penulis tertarik untuk membahas skripsi ini dengan rumusan maslah yaitu: Pertama, Bagaimanakah penerapan pengawasan oleh Majelis Pengawas Daerah (MPD) Kota Batam terhadap Notaris yang melakukan pelanggaran? Kedua Bagaimanakah efektivitas pelaksanaan pengawasan Majelis Pengawas Daerah (MPD) Kota Batam terhadap perilaku Notaris? 


\section{B. Metode Penelitian}

Metode Penelitian merupakan suatu tatanan ataupun susunan tata cara pelaksanaan ataupun sekumpulan prosedur dan kegiatan yang digunakan oleh Peneliti untuk melakukan suatu penelitian ilmiah, secara harafiah metodologi dapat diartikan sebagai analisis teoritis terhadap suatu tata cara maupun suatu metode sedangkan penelitian adalah suatu disiplin ilmu yang dilakukan oleh seseorang guna untuk menyelidiki suatu pokok permasalahan guna untuk meningkatkan pengetahuan akan sesuatu hal yang sedang diteliti guna untuk menemukan suatu jawaban atas pokok permasalahan yang akan dibahas didalam suatu penelitian oleh sebab itu Metode penelitian diperlukan sebagai suatu tolak ukur dan tata cara untuk mendapatkan sejumlah data yang akurat yang dapat dipertanggungjawabkan oleh Peneliti dimana data-data tersebut merupakan sejumlah data yang berkaitan langsung dengan pokok permasalahan yang akan Peneliti bahas didalam Penelitian karya ilmiah skripsi ini.

Penelitisn empiris ini menggunakan data primer dan sekunder. Data primer diperoleh langsung dari observasi lapangan oleh penulis dengan narasumber yang berkaitan dengan penulisan karya ilmiah, yaitu ketua Majelis Pengawas Daerah (MPD) kota Batam. Data sekunder adalah sebagai data pelengkap sumber data primer, terdiri dari 3 bahan hukum yaitu bahan hukum primer yaitu UndangUndang Nomor 2 Tahun 2014 tentang Perubahan atas Undang-Undang Nomor 30 Tahun 2004 tentang Jabatan Notaris (Undang-Undang Jabatan Notaris), Peraturan Menteri Hukum dan Hak Asasi Manusia Republik Indonesia, Kitab UndangUndang Hukum Perdata (KUHPerdata). Bahan hukum sekunder yaitu jurnal, karya ilmiah dan laporan. Dan data tersier yaitu Kamus Besar Bahasa Indonesia.

Kemudian penulis melakukan analisis data dengan analisis secara kualitatif. Data yang telah diperoleh, lalu diolah kemudian dianalisis setelah itu dilakukan dengan mengambarkan data yang dihasilkan dalam bentuk uraian kalimat atau penjelasan. Dari analisis data tersebut dilanjutkan dengan menarik kesimpulan secara induktif yaitu suatu cara berfikir yang didasarkan pada fakta-fakta yang bersifat umum, kemudian dilanjutkan dengan pengambilan kesimpulan yang bersifat khusus yang merupakan jawaban dari permasalahan berdasarkan hasil penelitian dan selanjutnya diberikan beberapa saran. ${ }^{5}$

\section{Hasil Penelitian dan Pembahasan}

\section{Penerapan Pengawasan oleh Majelis Pengawas Daerah (MPD) Kota Batam terhadap Notaris yang melakukan pelanggaran}

Majelis Pengawas Daerah (MPD) mempunyai wewenang untuk menerima laporan dari masyarakat dan dari Notaris lainnya dan menyelenggarakan sidang untuk memeriksa adanya dugaan pelanggaran pelaksanaan jabatan Notaris, akantetapi tidak diberi kewenangan untuk menjatuhkan sanksi apapun. Dalam hal ini, Majelis Pengawas Daerah (MPD) hanya berwenang untuk melaporkan hasil sidang dan pemeriksaannya kepada Majelis Pengawas Wilayah (MPW) dengan

\footnotetext{
${ }^{5}$ Lexy J. Moleong, Metodologi Penelitian Kualitatif, (Bandung: PT. Remaja Rosdakarya, 1999), hlm. 103
} 
tembusan kepada pihak yang melaporkan, Notaris yang bersangkutan, Majelis Pengawas Pusat (MPP) dan Organisasi Notaris.

Majelis Pengawas Daerah (MPD) hanya punya wewenang untuk memberikan rekomendasi kepada Notaris. Kemudian untuk Notaris yang dinyatakan melakukan pelanggaran maka, kasus tersebut akan ditindak lanjut oleh Majelis Pengawas Wilayah (MPW) mengenai Majelis Pengawas Wilayah berwenang untuk menjatuhkan sanksi berupa teguran lisan dan tertulis sesuai Pasal 73 ayat (1) huruf e Undang-Undang Jabatan Notaris. Sedangkan Majelis Pengawas Pusat berwenang untuk menyelenggarkan sidang ditingkat banding dan menjatuhkan sanksi berupa pemberhentian sementara.

Penjatuhan sanksi sebagaimana terurai diatas terhadap Notaris yang melakukan pelanggaran bukanlah pemecatan dari jabatan Notaris. Karena yang punya wewenang untuk memecat Notaris dari jabatannya hanyalah Menteri. Kemudian Majelis Pengawas Daerah (MPD) mempunyai kewenangan khusus yang tidak dipunyai oleh Majelis Pengawas Wilayah (MPW) dan Majelis Pengawas Pusat (MPP), yaitu sebagaimana yang tersebut dalam Pasal 66 UndangUndang Jabatan Notaris, bahwa Majelis Pengawas Daerah berwenang untuk memeriksa Notaris sehubungan dengan permintaan penyidik, penuntut umum atau hakim untuk mengambil fotokopi minuta atau surat-surat lainnya yang dilekatkan pada minuta atau dalam protokol Notaris dalam penyimpanan Notaris, juga pemanggilan Notaris yang berkaitan dengan akta yang dibuatnya atau dalam protokol Notaris yang berada dalam penyimpanan Notaris.

Menurut sifatnya kewenangan Majelis Pengawas Daerah (MPD) Notaris dibagi menjadi 4 (empat) yaitu:

a. Kewenangan Majelis Pengawas Daerah (MPD) yang berkaitan dengan pemeriksaan atas pengambilan Minuta Akta.

b. Melakukan pemeriksaan atas pemanggilan Notaris dalam proses peradilan.

c. Melakukan pemeriksaan terhadaap laporan masyarakat mengenai adanya dugaan pelanggaran Kode Etik oleh Notaris atau peraturan mengenai Jabatan Notaris.

d. Melakukan pemeriksaan terhadap protokol Notaris.

Menurut sifatnya, Kewenangan Majelis Pengawas Daerah Notaris dapat juga dikelompokkan menjadi:

a. Pengawas para Notaris di wilayah kerja Majelis Pengawas Daerah Notaris.

b. Pembina bagi para Notaris.

c. Pengontrol penyidik, penuntut umum dan hakim agar pemanggilan Notaris oleh penyidik, penuntut umum dan hakim tidak dilakukan dengan sembarangan.

Dalam menjalankan kewenangannya untuk memeriksa Notaris dilakkan dengan tata cara sesuai dengan ketentuan peraturan perundang-undangan yang berlaku sebagai berikut: 


\section{a. Pengajuan Laporan}

1) Laporan dapat diajukan oleh pihak yang merasa dirugikan.

2) Laporan harus disampaikan secara tertulis dalam Bahasa Indonesia disertai bukti-bukri yang dapat dipertanggungjawabakan.

3) Laporan tentang adanya dugaan pelanggaran pelaksanaan jabatan Notaris disampaikan kepada Majelis Pengawas Daerah (MPD).

4) Laporan masyarakat selain sebagaimana pada point (3) disampaikan kepada Majelis Pengawas Wilayah.

5) Dalam hal laporan sebagaimana dimaksud pada point (3) disampaikan kepada Majelis Pengawas Wilayah, maka Majelis Pengawas Wilayah meneruskan kepada Majelis Pengawas Daerah yang berwenang.

6) Dalam hal laporan sebagaimana dimasksud pada point (3) disampaikan kepada Majelis Pengawas Pusat, maka Majelis Pengawas Pusat meneruskannya kepada Majelis Pengawas Daerah yang berwenang.

\section{b. Pemanggilan}

1) Ketua Majelis Pemeriksa Melakukan Pemanggilan terhadap pelapor dan terlapor

2) Pemanggilan dilakukan dengan surat oleh sekretaris dalam waktu paling lambat 5 (lima) hari kerja sebelum sidang.

3) Dalam keadaan mendesak pemanggilan sebagaimana dimaksud pada point (2) dapat dilakukan melalui faksimili yang segera disusul dengan surat pemanggilan.

4) Dalam hal terlapor setelah dipanggil secara sah dan patut, tetapi tidak hadir maka dilakukan pemanggilan kedua.

5) Dalam hal terlapor setelah dipanggil secara sah dan patut, tetapi tidak hadir maka pemeriksaan dilakukan dan putusan diucapkan tanpa kehadiran terlapor.

6) Dalam hal pelapor setelah dipanggil secara sah dan patut tidak hadir, maka dilakukan pemanggilan yang kedua, dan apabila pelapor tetap tidak hadir maka Majelis Pemeriksa menyatakan laporan gugur dan tidak dapat diajukan lagi.

\section{c. Pemeriksaan oleh Majelis Pemeriksa Daerah}

1) Pemeriksaan oleh Majelis Pemeriksa Daerah tertutup untuk umum.

2) Pemeriksaan dimulai dalam jangka waktu paling lambat 7 (tujuh) hari kalender setelah laporan diterima.

3) Majelis Pemeriksa Daerah harus sudah menyelesaikan pemeriksaan dan menyampaikan hasil pemeriksaan dalam jangka waktu paling lambat 30 (tiga puluh) hari kalender terhitung sejak laporan diterima. 
4) Hasil pemeriksaan sebagaimana dimaksud pada point (3) dituangkan dalam berita acara pemeriksaan yang ditandatangani oleh ketua dan sekretaris.

5) Surat pengantar pengiriman berita acara pemeriksaan yang dikirimkan kepada Majelis Pengawas Wilayah ditembuskan kepada Pelapor, terlapor, Majelis Pengawas Pusat, dan Pengurus Daerah Ikatan Notaris.

Upaya yang dapat dilakukan oleh Majelis Pengawas Daerah (MPD) kota Batam dalam mencegah agar tidak terjadinya pelanggaran yang dilakukan oleh Notaris yaitu Majelis Pengawas Daerah (MPD) melakukan pengawasan langsung ke lapangan untuk mencegah agar tidak terjadinya pelanggaran dan sekaligus melakukan pengecekan akta di bulan Augustus. ${ }^{6}$

\section{Efektivitas Pelaksanaan Pengawasan Majelis Pengawas Daerah (MPD) Kota Batam terhadap perilaku Notaris}

Guna mengetahui keefektivitas daripada penerapan sanksi oleh pihak penyidik dalam menanggulangi oknum-oknum yang melanggar peraturan yang berlaku yang dilakukan oleh Notaris-Notaris di Wilayah Kota Batam maka peneliti melakukan wawancara secara langung dengan Nani Fitriyah, S.H selaku ketua Majelis Pengawasan Daerah mengenai penerapan sanksi sebagaimana telah diamanahkan oleh peraturan Undang-Undang tentang Jabatan Notaris dengan mengkaji berdasarkan teori efektivitas hukum yang dikemukan oleh ahli hukum Soejono Soekanto untuk melihat mengenai penerapan peraturan perundangundangan tentang jabatan Notaris dalam konteks penerapan tersebut telah efektif diberlakukan atau tidak.

Adapun Peneliti melakukan kajian terhadap keefektivitasan penerapan sanksi oleh pihak penyidik dalam menanggulangi agar tidak terjadinya pelanggaran peraturan yang dilakukan oleh Notaris di kota Batam dengan teori Soerjono Soekanto dengan lima Faktor Penilaian yang saling berkaitan adalah sebagai berikut:

a. Faktor Hukum

Faktor hukum yang dimaksudkan dalam teori efektivitas hukum adalah mengenai sekumpulan peraturan perundang-undangan ataupun landasan-landasan hukum yang cukup memadai dalam proses penengakan hukum itu sendiri sebab pada dasarnya fungsi utama daripada hukum itu sendiri adalah berfungsi untuk memberikan keadilan, kepastian dan kemanfaatan sebab dari sisi kepastian dan kemanfaatan hukum berifat konkrit yang bisa secara langsung dirasakan sedangkan dari sisi keadilan pada umumnya bersifat abstrak hingga adanya putusan hakim melalui pengadilan.

\footnotetext{
${ }^{6}$ Berdasarkan wawancara dengan Ketua Majelis Pengawasan Daerah Ibu Nani Fitryah, SH,pada tanggal 29 May 2019 hari Rabu di Komplek Pondok Asri Indah Blok E No. 12 Sungai Panas
} 
Hukum berfungsi untuk keadilan, kepastian dan kemanfaatan. Dalam praktik penyelenggaraan hukum di lapangan ada kalanya terjadi pertentangan antara kepastian hukum dan keadilan. Kepastian hukum sifatnya konkret berwujud nyata, sedangkan keadilan bersifat abstrak sehingga ketika seseorang hakim memutuskan suatu perkara secara penerapan undang-undang saja maka ada kalanya nilai keadilan itu tidak tercapai. Maka ketika melihat suatu permasalahan mengenai hukum setidaknya keadilan menjadi prioritas utama. Karena hukum tidakla semata-mata dilihat dari sudut hukum tertulis saja. ${ }^{7}$

Dalam melakukan kajian terhadap efektivitas hukum dari segi hukumnya sendiri maka Peneliti akan menggunakan beberapa elemen sebagai berikut untuk menganalisis apakah hukum tersebut sudah efektif atau tidak efektif:

1) Peraturan telah sesuai dengan kebutuhan yang hidup didalam lingkungan masyarakat.

2) Peraturan yang ada tidak saling bertentangan baik secara hirarki terhadap peraturan yang diatasnya maupun bertentangan dengan peraturan yang setara dengannya.

3) Peraturan yang ada hendaklah secara kualitatif serta dalam hal kuantitatif telah mengcukupi untuk memberikan perlindungan bagi masyarakat.

4) Proses perancangan serta pembuatan hingga pada penerbitannya suatu peraturan perundang-undangan tersebut telah sesuai dengan peraturan yang berlaku dan tidak melanggar aturanaturan yuridis yang ada.

Undang-Undang Jabatan Notaris telah dijelaskan secara tegas bahwa setiap Notaris hanya diperbolehkan memasang 1 (satu) buah papan nama di depan kantor/lingkungan kantornya dan dilarang memasang papan nama yang berbunyi Notaris atau Kantor Notaris, dari hasil wawancara dengan ibu Nani Fitriyah selaku ketua Majelis Pengawas Daerah Kota Batam (MPD) mengatakan bahwa setiap tahunnya Majelis Pengawasan Daerah (MPD) melakukan pemeriksaan ke lapangan tetapi berdasarkan observasi dan hasil penelitian penulis mendapatkan bahwa masih terdapat banyak Notaris yang memasang papan nama lebih dari satu dan di luar lingkungan kantornya. Dan juga memasang papan petunjuk dengan mencantumkan nama Kantor Notarisnya padahal telah diatur dalam Undang-Undang Jabatan Notaris. Maka penulis menilai bahwa faktor hukum dalam penerapan UndangUndang Jabatan Notaris oleh Mejalis Pengawasan Daerah dalam melakukan pengawasan dan pengendalian belumlah efektif.

7 Soerjono Soekanto. 2007, Faktor-Faktor yang Mempengaruhi Penegakan Hukum, Jakarta. Penerbit PT. Raja Grafindo Persada, Hal.8 
b. Faktor Penegak Hukum

Penegak hukum harus memiliki mentalitas atau kepribadian sebagai peranan penting untuk fungsi dari hukum, disaat peraturan atau Undang-Undang sudah baik disitulah akan ada masalah. Selama ini ada kecenderungan yang kuat dikalangan masyarakat untuk mengartikan hukum sebagai petugas atau penegak hukum, artinya hukum diidentikkan dengan tingkat laku nyata yang ditunjukkan oleh petugas atau penegak hukum. $^{8}$

Tingkah laku dari penegak hukum masih dipandang masyarakat kurang mencerminkan hal yang baik dengan tidak sepenuhnya melakukan tugas dan wewenangnya dalam melakukan pengawasan sehingga membuat masyarakat juga memandang kurang memiliki citra yang wibawa dari aparat penegak hokum

Aparat penegak hukum yang menegakkan sebuah aturan atas pelanggaran peraturan yang berlaku ialah Majelis Pengawasan Daerah yang memiliki wewenang untuk melakukan penegakan hukum terhadap pelanggaran peraturan yang berlaku. Dengan melakukan Pengawasan dan Pengendalian kepada pelaku pelanggaran sesuai kewenangan yang diatur dalam Undang-Undang Jabatan Notaris.

Berdasarkan hasil wawancara peneliti menyimpulkan bahwa dari sisi faktor penegakkan hukum terhadap Notaris di Kota Batam Belum optimal hal ini dikarenakan Peneliti masih banyak menemukan Notaris yang melanggar peraturan sebagaimana dalam Undang-Undang Jabatan Notaris masih banyak pelaku Notaris yang tidak mematuhi peraturan yang telah diatur. Salah satu contoh kasus adalah manipulasi Akta dan pemalsuan tanda tangan berdasarkan laporan yang di terima sama bu Nani Fitryah, SH. Sehingga hal ini membuat faktor Notaris sendiri tidak efektif karena ketidakpatuhan tersebut Selain ketidaksadaran Notaris, sebagai petugas hukum atau penegak hukum juga tidak melakukan pemantauan yang ketat terhadap Notaris-notaris.

c. Faktor sarana atau fasilitas pendukung

Faktor sarana atau fasilitas pendukung mencakup perangkat lunak dan perangkat keras, menurut Soerjono Soekanto bahwa para penegak hukum tidak dapat bekerja dengan baik, apabila tidak dilengkapi dengan kendaraan dan alat-alat komunikasi yang proporsional. Oleh karena itu, sarana atau fasilitas mempunyai peranan yang sangat penting di dalam penegak hukum. Tanpa adanya sarana atau fasilitas tersebut tidak akan mungkin penegak hukum menyeasikan peranan yang aktual.

Mengenai faktor sarana dan prasarana di Majelis Pengawas Daerah Kota Batam tidak mengalami kendala dalam perlengkapan alat-alat

\footnotetext{
${ }^{8}$ Ibid. Hal. 21
} 
komputer dan lain sebagainya dan sarana perlengkapan lapangan untuk pejabat fungsional seperti kendaraan dan peralatan lainnya.

d. Faktor masyarakat

Penegak hukum berasal dari masyarakat dan bertujuan untuk mencapai kedamaian di dalam masyarakat atau kelompok sedikit banyaknya mempunyai kesadaran hukum. Persoalan yang timbul adalah taraf kepatuhan hukum, yaitu kepatuhan hukum yang tinggi, sedang, atau kurang. Adanya derajat kepatuhan hukum masyarakat terhadap hukum, merupakan salah satu indikator berfungsinya hukum yang bersangkutan.

Masyarakat juga mempunyai peranan dalam melakukan pencegahan terhadap pelanggar atau penyimpangan yang dapat dilakukan oleh seorang Notaris. Dimana Masyarakat dapat melaporkan kepada Majelis Pengawas Notaris atas kerugian yang ia derita terhadap layanan yang diberikan Notaris. Disini faktor masyarakat belumlah efektif dikarenakan peneliti masih banyak menemukan masyarakat yang tidak mengetahui harus melapor kemana. masyarakat dinilai masih pasif.

e. Faktor kebudayaan

Kebudayaan pada dasarnya mencakup nilai-nilai yang mendasari hukum yang berlaku, nilai-nilai mana yang merupakan konsepsi-konsepsi yang abstrak mengenai apa yang dianggap baik (sehingga dituruti) dan apa yang dianggap buruk (sehingga dihindari). Maka, kebudayaan Indonesia merupakan dasar atau mendasari hukum adat yang berlaku. Disamping itu berlaku pula hukum tertulis (perundang-undangan), yang dibentuk oleh golongan tertentu dalam masyarakat yang mempunyai kekuasaan dan wewenang untuk itu. Hukum perundang-undangan tersebut harus dapat mencerminkan nilai-nilai yang menjadi dasar dari hukum adat, agar hukum perundang-undangan tersebut dapat berlaku secara aktif.

Kebudayaan serta kebiasaan yang timbul dalam beberapa kelompok masyarakat Kota Batam yaitu jika tidak ada aturan yang mengatur maka tidak akan tunduk pada hukum dan untuk kebiasaan yang dilakukan oleh Notaris salah satu contohnya adalah peraturan terhadap dilarang untuk memasang papan nama diluar kantor namun dikarenakan ada yang memasang papan nama diluar kantor sehingga menjadi suatu kebiasaan dan diikutin oleh Notaris lain, dan pada saat ditegur oleh Majelis Pengawas Daerah pihak oknum tersebut mengatakan bahwa Notaris A juga melakukan hal tersebut. ${ }^{9}$ sehingga hal tersebut menjadi suatu kebiasaan yang terjadi di dunia kenotarisan sekarang. Inilah

\footnotetext{
${ }^{9}$ Berdasarkan wawancara dengan Ketua Majelis Pengawasan Daerah Ibu Nani Fitryah, SH,pada tanggal 29 May 2019 hari Rabu di Komplek Pondok Asri Indah Blok E No. 12 Sungai Panas
} 
sebaiknya diperbaiki oleh pemerintah dalam menindak lanjuti kegiatankegiatan yang berdampak pada sekitarnya.

Efektivitas sendiri merupakan suatu tolak ukur tercapainya tujuan yang telah ditentukan. Efektivitas hukum merupakan sebuah proses bagaimana agar suatu hukum itu berjalan secara efektif. Untuk mengetahui efektifnya sebuah hukum, maka hal pertama yang harus kita ketahui adalah sejauh mana hukum tersebut ditaati oleh target-target yang menjadi sasaran ketaatan tersebut.

Kelima faktor efektivitas hukum diatas adalah menjadi sentral untuk mengukur sejauh mana efektifnya sebuah hukum. Dapat dilihat bahwa efektivitas atas penegakan hukum terhadap Notaris di kota Batam oleh Majelis Pengawasan Daerah berdasarkan Undang-Undang No. 2 Tahun 2014 tentang perubahan Undang-Undang Nomor 30 Tahun 2014 tentang jabatan Notaris belum terlaksana secara efektif dikarenakan dalam pengawasan ini dapat dilihat masih terdapat Notaris yang melakukan pelanggaran Kode Etik khusunya dalam pengaturan penunjuk arah kantor dan papan nama Notaris.

Jabatan Notaris merupakan jabatan yang mendapat kepercayaan karena seorang Notaris, didalam menjalankan jabatan tersebut tidak semata-mata hanya dituntut keahlian dibidang ilmu kenotariatan saja, namum mereka perlu memiliki ahklak tinggi. Sehingga dalam melaksanakan tugas dan kewajibannya dapat berpegang terhadap Undang-undang Jabatan Notaris dan Kode Etik Profesi Notaris ${ }^{10}$

Berikut yang diberikan oleh Majelis Pengawasan Daerah terhadap Kasus yang ditemukan Majelis Pengawasan Daerah Terkait Pelanggaran Notaris, antara lain:

a. Terdapatnya pemalsuan akta. Namun setelah Majelis Pengawas Daerah melakukan pemeriksaan, Notaris tersebut mengatakan bahwa Tanda Tangan tersebut bukanlah tanda tangan beliau. Beliau mengatakan bahwa untuk melakukan tanda tangan di akta beliau menggunakan pena khusus milik beliau.

b. Terhadap kasus ini, Majelis Pengawas daerah kota Batam memberikan Rekomendasi kepada Notaris untuk upaya penanggulan dalam mencegah agar tidak terjadi lagi pelanggaran adalah pada kasus pertama Ketua Majelis Pengawas Daerah kota Batam menyuruh setiap Notaris yang ingin tanda tanganin akta harus membuat lembaran sidik jari dan dokumentasi pada saat mentanda tanganin akta, bahwa akta A telah di tanda tangani pada hari dan tanggal sekian.

\section{Kesimpulan}

Kesimpulan yang dapat diambil berdasarkan hasil analisis data tentang "Efektivitas Peranan Majelis Pengawas Daerah dalam Penegakan Kode Etik

\footnotetext{
${ }^{10}$ Berdasarkan wawancara dengan Ketua Majelis Pengawasan Daerah Ibu Nani Fitryah, SH,pada tanggal 29 May 2019 hari Rabu di Komplek Pondok Asri Indah Blok E No. 12 Sungai Panas
} 
Notaris Berdasarkan Undang-Undang Nomor 2 Tahun 2014 tentang Perubahan Atas Undang-Undang Nomor 30 Tahun 2004 tentang Jabatan Notaris (Studi lapangan Kota Batam)" sebagai berikut:

1. Dalam melaksanakan penerapan pengawasan oleh Majelis Pengawas Daerah di Kota Batam bahwa Majelis Pengawas Daerah mempunyai wewenang untuk menerima laporan dari masyarakat dan dari Notaris lainnya dan memeriksa adanya dugaan pelanggaran pelaksanaan jabatan Notaris, tetapi tidak diberi kewenangan untuk menjatuhkan sanksi apapun. Dalam hal ini Majelis Pengawas Daerah hanya melaporkan hasil sidang dan hasil pemeriksaan kepada pihak yang melaporkan, Notaris yang bersangkut, Majelis Pengawas Pusat, dan Organisasi Notaris. Kemudian Majelis Pengawas Daerah hanya bisa memberikan rekomendasi saja ke Notaris yang bersangkut.

2. Mengukur keefektivitas penerapan Undang-Undang jabatan Notaris, penulis menggunakan teori Soerjorno Soekanto dalam melakukan tolak ukur tingkat efektivitas penagakan hukum.

Dapat dilihat bahwa keefektivitas atas penegakan hukum terhadap Notaris di kota Batam oleh Majelis Pengawasan Daerah (MPD) berdasarkan UndangUndang Nomor 2 Tahun 2014 Tentang Perubahan Undang-Undang Nomor 30 Tahun 2004 Tentang jabatan Notaris belum terlaksanakan secara efektif dikarenakan masih banyak Notaris yang melakukan pelanggaran. 


\section{Daftar Pustaka Buku}

\section{Buku}

Pengurus Pusat Ikatan Notaris Indonesia, Jati Diri Notaris Indonesia Dulu, Sekarang dan di Masa Datang, PT. Gramedia Pustaka Utama, Jakarta, 2008

Tim Penyusun Kamus Pusat Pembinaan dan Pengembangan Bahasa, Kamus Besar Bahasa Indonesia, Penerbit Balai Pustaka, Jakarta, 1990

Lumban TobingG.H.S., 1999, Peraturan jabatan Notaris, Jakarta, Erlangga

Habib Adjie, Hukum Notaris Indonesia, Tafsir Terhadap UU No.30 Tahun 2004 Tentang Jabatan Notaris, Refika Aditama, Bandung, 2008

Sutrisno, Tanggapan Terhadap Undang-Undang, No, 30 Tahun 2004 tentang Jabatan Notaris, (Bahan Kuliah Etika Profesi Notaris), Mkn USU, 2007

Wawan Setiawan, Kedudukan dan Keberadaan serta Fungsi dan Peranan Notaris Sebagai Pejabat Umum Menurut Sistem Hukum di Indonesia, Bandung Alumni, 1998.

R. Subekti dan R. Tjitrosudibio, Kamus Hukum, Pradnya Paramita, Jakarta, 1980

Sudikno Mertokusumo, Hukum Acara Perdata Indonesia, Liberty, Yogyakarta, 1981

Sudikno Mertokusumo, Hukum Acara Perdata di Indonesia, Liberty, Yogyakarta, 1998

Rachmat Setiawan, 1987, Pokok-Pokok Hukum Perikatan, Bina Cipta, Bandung, 1987

Soerjono Soekanto, pokok-pokok Sosiologi Hukum, PT Raja Grafindo Persada, Jakarta 2007

Soerjono Soekanto, factor-faktor yang Memegaruhi Penengak HukumPT Raja Grafindo Persada, Jakarta, 2005

G.H.S Lumban Tobing, Peraturan Jabatan Notaris, Erlangga, Jakarta, 1983

Soerjono Soekanto. 2007, Faktor-Faktor yang Mempengaruhi Penegakan Hukum, PT. Raja Grafindo Persada, Jakarta, 2007

\section{Peraturan Perundang-undangan}

Kitab Undang-undang Hukum Perdata [Burgelijk Wetboek]. Diterjemahkan oleh R. Subekti dan R. Tjitrosudibio. Jakarta: Pradnya Paramita, 2005.

Undang-Undang Nomor 2 Tahun 2014 Tentang Perubahan Undang-Undang Nomor 30 Tahun 2004 Tentang Jabatan Notaris (Lembaran Negara Republik Indonesia (Lembaran Negara Republik Indonesia Tahun 2014 Nomor 3, Tambahan Lembaran Negara Republik Indonesia Nomor 5491)

Peraturan Menteri Hukum dan Hak Asasi Manusia Republik Indonesia Nomor: M.02.PR.08.10 Tahun 2004 


\section{Jurnal}

Dwikky Bagus Wibisono, "Peranan Majelis Pengawas terhadap Pengawasan Pelaksanaan Jabatan Notaris di Kabupaten Tegal". Vol 5 No 1 Maret 2018

Yogi Priyambodo, "Tinjauan Terhadap Pelanggaran Kode Etik Jabatan Notaris di Kabupaten Purbalingga". Vol. 4 No. 3 September 2017

Sri Yuniati, "Mekanisme Pemberian Sanksi Terhadap Notaris yang Melakukan Pelanggaran Kode Etik Jabatan Notaris". Vol. 4 No. 4 Desember 2017

Sri Utami, "Perlindungan Hukum Terhadap Notaris Dalam Proses Peradilan Pidana Menurut Undang-Undang Nomor 2 Tahun 2014 Tentang Perubahan Atas Undang-Undcang Nomor 30 Tahun 2004 Tentang Jabatan Notaris", artikel pada jurnal Repertorium ISSN: 2355-2646, Edisi 3 januari-juni 2015

Suharjono, "Sekilas Tinjauan Akta Menurut Hukum”, Varia Peradilan Tahun XI Nomor 123, Desember 1995 